Dikirim: 31 Desember 2016 Diterbitkan: 1 April 2017

\title{
Pengetahuan dan sikap orang tua terhadap status imunisasi anak di Bantul
}

\section{Knowledge and attitudes of parents about child immunization status in Bantul}

Titik Mariati ${ }^{1}$, Djauhar Ismail ${ }^{2}$, Mohammad Hakimi $^{1}$

\begin{abstract}
Purpose: The purpose of this paper was to determine the relationship of knowledge, and parental attitudes with the status of child immunization in the working area of Puskesmas Banguntapan II Bantul Yogyakarta. Methods: A cross-sectional study was conducted involving the mothers of 0-12 months old children in the working area of Banguntapan II Bantul Yogyakarta Primary Health Care. Simple random sampling was used. Results: The results showed that there was a significant attitude relationship with the immunization status of their children with high category as much as $86.9 \%$. These results showed that as much as $86.9 \%$ immunization status of children are not complete. The OR value of knowledge was 0.7 with a $\mathrm{Cl}$ value of 0.15 to 4.04 . This model shows that the knowledge of respondents with parental attitudes is meaningful both statistically and practically. Conclusion: This study contributes to the knowledge that there is a significant relationship between parental attitudes with child immunization status in the working area of Banguntapan II Bantul Yogyakarta Primary Health Care.
\end{abstract}

Keywords: knowledge; attitude; immunization status

\footnotetext{
${ }^{1}$ Departemen Biostatistik, Epidemiologi, dan Kesehatan Populasi, Fakultas Kedokteran, Universitas Gadjah Mada (Email: titik_pct@yahoo.com)

${ }^{2}$ Departemen Ilmu Kesehatan Anak, Fakultas Kedokteran, Universitas Gadjah Mada
} 


\section{PENDAHULUAN}

Angka kematian bayi (AKB) dalam dua dasawarsa terakhir ini menunjukkan penurunan yang bermakna. Indonesia berhasil menurunkan AKB dari 71 menjadi 54 pada tahun 1985 sampai 1990. Angka kematian bayi menurun hingga 32 per 1000 kelahiran hidup pada tahun 2012. Penurunan tersebut diikuti dengan penurunan angka kematian balita atau AKABA yang telah mencapai 40 per 1000 kelahiran hidup (1).

Penyebab kematian anak di bawah satu tahun secara berurutan adalah kematian perinatal, infeksi saluran napas, diare, penyakit terkait saluran cerna, tetanus dan penyakit neurologi. Diperkirakan 5\% dari kematian balita di Indonesia adalah akibat penyakit yang dapat dicegah dengan imunisasi (PD3I) (2,3). Contoh penyakit menular penyebab kematian adalah dipteri, tetanus, dan hepatitis B (4).

WHO kembali menyerukan urgensi imunisasi dengan slogan "Ketahui, Cek dan Lindungi (know, check and protect)". WHO mengatakan bahwa, "Imunisasi sudah berhasil mencegah 2-3 juta kematian setiap tahunnya. Anak-anak sebagai kelompok yang rentan terhadap penyakit menjadi salah satu sasaran utama pencapaian imunisasi. Melalui imunisasi anak-anak bisa terlindungi dari penyakit-penyakit fatal seperti difteri, measles, pertusis, pneumonia (penyebab 5000 kematian anak Indonesia tahun 2013), polio, diare (penyebab ke-2 kematian anak Indonesia tahun 2013), rubella dan tetanus” (5). Ikatan Dokter Anak Indonesia (IDAI) mengeluarkan jadwal imunisasi anak sesuai rekomendasi terbaru untuk tahun 2014. Pembaharuan dari jadwal ini adalah penambahan vaksin influenza sebagai salah satu imunisasi yang direkomendasikan kepada anak-anak (1).

Alasan utama anak tidak diimunisasi adalah pengetahuan dan sikap orangtua, sikap dan praktik petugas kesehatan, kendala layanan kesehatan, kontra indikasi palsu, pengetahuan praktis orang tua tentang vaksinasi, takut efek samping dan lain-lain (6). Dari data puskesmas didapatkan bahwa di desa Wirokerten terdapat balita laki-laki yang tidak imunisasi sebanyak 80 dari total 84 balita. Balita perempuan yang tidak imunisasi sebanyak 70 dari total perempuan sebanyak 87 balita. Total balita yang tidak diimunisasi atau status imunisasi kurang sebanyak 171 balita. Dari keempat desa di atas terdapat paling banyak balita tidak diimunisasi di desa Wirokerten.

Penelitian ini secara umum bertujuan untuk mengetahui hubungan pengetahuan dan sikap dengan status imunisasi anak di wilayah kerja puskesmas Banguntapan II, Bantul, Yogyakarta

\section{METODE}

Penelitian ini adalah penelitian non-eksperimental dengan rancangan cross sectional study. Populasi dalam penelitian ini adalah orang tua yang mem- punyai balita usia 0-12 bulan yang berada di wilayah kerja puskesmas di desa Wirokerten, dengan jumlah balita usia 0-12 bulan sebanyak 171 balita.

Pengambilan data dilakukan dengan wawancara yang dilakukan pada orang tua yang mempunyai balita usia 0-12 bulan. Pengambilan data meliputi pengetahuan orang tua tentang imunisasi, sikap, pendidikan, pekerjaan, umur, orang tua, perilaku ibu dalam meberikan imunikasi, dan pernolong persalinan.

Dalam penelitian ini pengetahuan dan sikap adalah variabel bebas dan status imunisasi adalah variabel terikat. Instrumen penelitian yang digunakan dalam penelitian ini adalah kuesioner yang terlebih dahulu telah dilakukan uji validitas dan reliabilitas. Uji kuesioner dilakukan di wilayah kerja puskesmas Banguntapan II Bantul Yogyakarta. Variabel status imunisasi diambil dari kartu menuju sehat tahun 2016.

Analisis data dan uji statistik yang akan dilakukan dalam penelitian ini meliputi analisis deskriptif yang disajikan dalam bentuk distribusi frekuensi, persentase, serta narasi dan analisis inferensial yang meliputi analisis bivariabel dengan menggunakan uji statistik chi-square dan t-test, dan 95\% confidence interval (CI) serta nilai kemaknaan $\mathrm{p}<0,05$. Analisis multivariat menggunakan regresi logistik. ada analisis multivariabel ini variabel yang diuji adalah variabel yang mempunyai nilai $(\mathrm{p}<0,05)$ pada uji bivariabel. Uji hipotesis yang digunakan adalah uji conditional regression logistic dengan tingkat kemaknaan $\alpha=0,05$ dan $95 \%$ CI. Nilai -2log likehood digunakan untuk membandingkan perbedaan model 1 dengan model lainnya. Perbedaan model dikatakan bermakna secara statistik apabila nilai -2log likehood lebih besar dari nilai X2 tabel dengan derajat bebas dihitung dari perbedaan derajat dua model.

\section{HASIL}

Tabel 1 menunjukkan aspek karakteristik subjek penelitian. Secara umum sebagian besar responden memiliki karakteristik tidak diimunisasi, dengan jumlah sebanyak 50 (76,9\%). Berdasarkan hasil kuesioner diketahui bahwa pengetahuan tinggi dari responden sebanyak 55 (84,6\%). Mayoritas responden berusia 20 - 35 tahun $(56,92 \%)$. 
Tabel 1. Distribusi frekuensi karakteristik responden

\begin{tabular}{lc}
\hline \multicolumn{1}{c}{ Karakteristik } & $\begin{array}{c}\text { Persentase (\%) } \\
(\mathbf{n}=63)\end{array}$ \\
\hline Karakteristik Imunisasi & \\
Imunisasi lengkap (n=15) & 23.1 \\
Imunisasi Tidak Lengkap (n=50) & 76.9 \\
Pengetahuan & \\
Tinggi (n=55) & 84.6 \\
Rendah (n=10) & 15.4 \\
Pendidikan & \\
Tinggi (n=42) & 64.6 \\
Rendah (n=23) & 35.4 \\
Pekerjaan & \\
Tidak Bekerja (n=50) & 76.9 \\
Bekerja (n=15) & 23.1 \\
Umur & \\
20-35 tahun (n=37) & 56.9 \\
$<20$ tahun dan >35 tahun (n=28) & 43.1 \\
Penolong Persalinan & \\
Rumah Sakit (n=10) & 15.4 \\
Puskesmas (n=10) & 15.4 \\
Bidan (n=45) & 69.2 \\
Kriteria Sikap & \\
Positif (n=19) & 29.2 \\
Negatif (n=46 & 70.8 \\
\hline
\end{tabular}

Tabel 2 menunjukkan responden dengan status imunisasi lengkap dan berpengetahuan tinggi sebanyak 22\%, sementara responden dengan status imunisasi yang tidak lengkap dengan pengetahuan yang tinggi sebanyak $78 \%$. Responden dengan status imunisasi lengkap dengan sikap positif sebanyak 47,4\% dan status imunisasi yang tidak lengkap dengan sikap yang negatif sebanyak $86,9 \%$.

Tabel 2. Hasil Analisis bivariat hubungan pengetahuan dan sikap orang tua dengan status imunisasi anak

\begin{tabular}{|c|c|c|c|c|}
\hline \multirow{2}{*}{ Variabel } & \multicolumn{2}{|c|}{ Kelengkapan imunisasi } & \multirow{2}{*}{$\mathbf{R P}$} & \multirow{2}{*}{ CI 95\% } \\
\hline & Lengkap & Tidak lengkap & & \\
\hline \multicolumn{5}{|c|}{ Pengetahuan } \\
\hline Tinggi & 12 & 43 & 0,73 & $0,25-2,13$ \\
\hline Rendah & 3 & 7 & & \\
\hline \multicolumn{5}{|l|}{ Sikap } \\
\hline Positif & 9 & 10 & 3,63 & $1,5-8,8^{*}$ \\
\hline Negatif & 6 & 40 & & \\
\hline
\end{tabular}

Tabel 3 menunjukkan perbandingan model regresi logistik. Model 1 menjelaskan hubungan pengetahuan pada sikap orang tua dengan status imunisasi anak tanpa mempertimbangkan variabel yang lain. Nilai OR pengetahuan sebesar 0,7 dengan nilai CI 0,15- 4,04. Model ini menunjukkan bahwa pengetahuan responden dengan sikap orang tua bermakna baik secara statistik maupun praktis.
Tabel 3. Perbandingan model regresi logistik

\begin{tabular}{|c|c|c|c|}
\hline Variabel & $\begin{array}{l}\text { Model 1 } \\
\text { OR } \\
\text { CI 95\% }\end{array}$ & $\begin{array}{l}\text { Model } 2 \\
\text { OR } \\
\text { CI 95\% }\end{array}$ & $\begin{array}{l}\text { Model } 3 \\
\text { OR } \\
\text { CI 95\% }\end{array}$ \\
\hline \multicolumn{4}{|l|}{ Pengetahuan } \\
\hline Tinggi & $\begin{array}{l}0,7 \\
0,15-4,04\end{array}$ & $\begin{array}{l}1,1 \\
0,17-7,95\end{array}$ & $\begin{array}{l}1,1 \\
0,17-7.9\end{array}$ \\
\hline \multicolumn{4}{|l|}{ Sikap } \\
\hline Positif & $\begin{array}{l}5,9 \\
0,6-20.5\end{array}$ & $\begin{array}{l}9,1 \\
2,17-38,6\end{array}$ & $\begin{array}{l}9,1 \\
2,16-3,6\end{array}$ \\
\hline \multicolumn{3}{|l|}{ Pendidikan } & Ref \\
\hline Tinggi & & $\begin{array}{l}1,1 \\
0,27-4,69\end{array}$ & $\begin{array}{l}1,1 \\
0,27-4.69\end{array}$ \\
\hline \multicolumn{4}{|l|}{ Pekerjaan } \\
\hline Tidak Bekerja & & $\begin{array}{l}6,9 \\
0,67-71,8\end{array}$ & $\begin{array}{l}6,9 \\
0,67-71,7\end{array}$ \\
\hline $\begin{array}{l}\text { Bekerja } \\
\text { Umur }\end{array}$ & & Ref & Ref \\
\hline $20-35$ thn & & $\begin{array}{l}6,9 \\
0,67-71,85\end{array}$ & $\begin{array}{l}0,9 \\
0,2-3,58\end{array}$ \\
\hline $\begin{array}{l}<20 \text { dan }>35 \text { thn } \\
\text { Tempat Persalinan }\end{array}$ & & Ref & Ref \\
\hline Rumah Sakit & & & $\begin{array}{l}4,5 \\
0,41-50.9\end{array}$ \\
\hline Puskesmas & & & $\begin{array}{l}3,1 \\
0,43-23,7\end{array}$ \\
\hline Bidan & & & Ref \\
\hline $\bar{n}$ & 63 & 63 & 63 \\
\hline -2Log Likelihood & 8,4 & 12,4 & 12,4 \\
\hline$\overline{\mathbf{R}^{2}}$ & 0,11 & 0,17 & 0,17 \\
\hline
\end{tabular}

(ODD Ratio) dihitung menggunakan uji logistik regresi

\section{BAHASAN}

Penelitian ini menemukan sebagian besar responden tidak diimunisasi. Mayoritas orang tua berpengetahuan tinggi dan tidak bekerja. Orang tua dominan memiliki sikap negatif terhadap kelengkapan imu- nisasi. Penelitian menemukan responden dengan status imunisasi lengkap dengan pengetahuan tinggi sebanyak $22 \%$ dan status imunisasi yang tidak lengkap dengan pengetahuan yang tinggi sebanyak $78 \%$. Hasil ini menunjukkan bahwa yang dimiliki orang tua/ibu balita persentasenya baik yang paling besar dominan, hal ini tidak lepas dari karakteristik yang dimiliki responden, salah satunya adalah pendidikan.

Tingkat pendidikan seseorang merupakan salah satu proses perubahan perilaku, dengan semakin tinggi pendidikan seseorang, semakin diperhitungkan dalam memiliki tempat pelayanan kesehatan. Semakin tinggi pengetahuan dan pendidikan seseorang, semakin membutuhkan pusat pelayanan kesehatan bagi diri dan keluarga. Dengan wawasan pengetahuan yang tinggi, seseorang akan semakin memiliki kesadaran mengenai pentingnya kesehatan bagi kehidupan dan termotivasi untuk melakukan kunjungan ke pusatpusat pelayanan kesehatan yang lebih baik. Orangtua atau ibu balita yang berpengetahuan tinggi cenderung 
menjadikan individu akan lebih cenderung untuk mencari informasi tentang hal-hal yang menyangkut tentang kesehatan diri maupun keluarga (7). Semakin tinggi pendidikan seseorang, maka pengetahuan akan semakin tinggi, begitu juga sebaliknya, walaupun pengetahuan atau informasi bisa didapatkan dari teman atau lingkungan tempat tinggal (8).

Responden dengan status imunisasi lengkap dengan sikap positif sebanyak $47,4 \%$ dan status imunisasi yang tidak lengkap dengan sikap yang negatif sebanyak $86,9 \%$. Hasil analisis menyimpulkan bahwa variabel sikap secara statistik bermakna, sehingga dapat dikatakan bahwa walaupun pengetahuan responden tinggi, sikap terhadap status imunisasi anak rendah.

WHO menyebutkanis bahwa perilaku seseorang didasari pemikiran dan perasaan (thoughts and feeling), dalam bentuk pengetahuan, persepsi, sikap, kepercaya- an dan penilaian terhadap objek (dalam hal ini objek kesehatan). Menurut Azwar faktor yang memengaruhi pembentukan sikap seseorang adalah pribadi, ke- budayaan, orang lain yang dianggap penting, media massa, institusi atau lembaga pendidikan atau lembaga agama, serta emosi dalam diri individu (9). Sikap belum otomatis terwujud dalam perbuatan nyata diperlukan faktor pendukung atau kondisi yang memungkinkan, antara lain fasilitas. Di samping itu perlu dukungan dari berbagai pihak, seperti petugas, suami istri, orang tua, teman dan lain-lain (10).

Pemberian imunisasi dasar lengkap untuk pemberian perlindungan menyeluruh karena tubuh akan dirangsang untuk memiliki kekebalan terhadap penyakit-penyakit yang berbahaya. Penelitian di Tanzania menemukan bahwa cakupan imunisasi yang rendah berhubungan dengan kematian anak. Hal ini tentu sangat rendah dibandingkan dengan indikator pencapaian UCI (Universal Child Immunization) sesuai dengan Keputusan Menteri Kesehatan Nomor 482/ MENKES/SK/IV/2010 mengenai akselerasi Imunisasi Nasional Universal Child Immunization 2010-2014.

\section{SIMPULAN}

Ada hubungan signifikan antara sikap dengan status imunisasi dengan nilai $47,4 \%$ dan status imunisasi yang tidak lengkap dengan sikap yang negatif sebanyak $86,9 \%$. Artinya, terdapat hubungan yang bermakna antara sikap dengan status imunisasi anak. Terdapat hubungan yang bermakna antara sikap dengan perilaku imunisasi dengan status imunisasi anak.

\begin{abstract}
Abstrak
Tujuan: Penelitian ini bertujuan untuk mengetahui hubungan antara pengetahuan, sikap orang tua dengan status imunisasi anak di wilayah kerja Puskesmas Banguntapan II Bantul Yogyakarta.
\end{abstract} Metode: Penelitian cross-sectional dilakukan melibatkan ibu balita usia 0-12 bulan di wilayah kerja puskesmas Banguntapan II Bantul Yogyakarta. Pengambilan sampel menggunakan random sampling. Hasil: Hasil menunjukkan bahwa terdapat hubungan sikap yang bermakna dengan status imunisasi anak dengan kategori tinggi sebanyak $86,9 \%$. Hasil di atas menunjukkan bahwa sebanyak $86,9 \%$ status imunisasi anak tidak lengkap. Nilai OR pengetahuan sebesar 0,7 dengan nilai CI 0,15- 4,04. Model ini menunjukkan pengetahuan responden dengan sikap orangtua bermakna, baik secara statistik maupun praktis. Simpulan: Penelitian ini memberikan kontribusi pengetahuan bahwa terdapat hubungan signifikan antara sikap dengan status imunisasi anak di wilayah kerja puskesmas Banguntapan II Bantul Yogyakarta.

Kata Kunci: pengetahuan; sikap; status imunisasi

\section{PUSTAKA}

1. IDAI. Pedoman imunisasi di Indonesia, Jakarta:Ikatan Dokter Anak Indonesia. 2014.

2. Depkes RI. Profil Kesehatan Indonesia tahun 2007. Jakarta:Departemen Kesehatan RI. 2008.

3. Ranuh, I, Suyitno, H, Hadinegoro, S, Kartasasmita, C. Pedoman imunisasi di Indonesia. Jakarta:IDAI. 2005.

4. BPS \& Macro International. Survei Demografi dan Kesehatan Indonesia. Calverton, Maryland, USA:Macro International. 2012.

5. WHO. World Immunization Week 2014 [Online]. 2014. Available: http://infoimunisasi .com/ [Accessed 4 April 2016].

6. Favin M, Steinglass R, Fields R, Banerjee $\mathrm{K}$, Sawhney M. Why children are not vaccinated: a review of the grey literature. International health. 2012 Dec 1;4(4):229-38.

7. Lestari RI, Masruroh. (2012). Hubungan Pengetahuan Ibu Tentang Imunisasi Dasar Lengkap Dengan Praktik Imunisasi Dasar Lengkap Bayinya Di Wilayah Kerja Puskesmas Pegandon Kec. Pegandon kab. Kendal. Jurnal Ilmiah Kesehatan Akbid Uniska Kendal.

8. Bugvi AS, Rahat R, Zakar R, Zakar MZ, Fischer F, Nasrullah M, Manawar R. Factors associated with non-utilization of child immunization in Pakistan: evidence from the Demographic and Health Survey 2006-07. BMC public health. 2014 Dec;14(1):232. 
9. Azwar, S. Sikap Manusia: Teori dan Pengukurannya, Yogyakarta:Pustaka Pelajar. 2013.

10. Notoatmodjo S. Promosi kesehatan dan ilmu perilaku. Jakarta: Rineka Cipta. 2007;20. 
Berita Kedokteran Masyarakat, Volume 33 No. 4 Tahun 2017 